\title{
O discurso narrativo em A Ilha Perdida, de Maria José Dupré E A Casa da Madrinha, de Lygia Bojunga $^{1}$
}

Alice Atsuko Matsuda alicem@utfpr.edu.br Universidade Tecnológica Federal do Paraná, Curitiba, Brasil.

Eliane Aparecida Galvão Ribeiro Ferreira

eliane@assis.unesp.br

Universidade Estadual Paulista, Assis, Brasil.

\section{RESUMO}

O presente artigo tem por objetivo analisar as disposições discursivas do narrador em duas obras de autoras diversas, respectivamente: A ilha perdida, de Maria José Dupré, e A casa da madrinha, de Lygia Bojunga Nunes. Para a consecução do objetivo, pretendemos observar o porquê da obra de Dupré, marcada pelo discurso monológico e pela soberania do narrador, ser considerada atraente pelos jovens; e da obra de Bojunga, caracterizada pelo discurso polifônico, ser apontada pelos jovens leitores como de difícil leitura. Por meio do suporte teórico da estética da recepção, buscamos apresentar uma possibilidade de leitura de ambas, refletindo acerca das disposições do narrador e de sua interferência no papel do leitor implícito. Além disso, pretendemos refletir sobre o horizonte de expectativa dos jovens leitores que aprovam a obra de Dupré e rejeitam a de Bojunga.

PALAVRAS-CHAVE: Narrador e Leitor. Estética da recepção. Horizonte de expectativa. Maria José Dupré. Lygia Bojunga Nunes. Infantil e Juvenil: Letramento literário e Diversidade, na UFSC, Florianópolis, de 11 a 13 de abril de 2012. 


\section{INTRODUÇÃO}

Como professoras de literatura, desenvolvemos pesquisas de campo direcionadas para a formação do leitor. Durante esse trabalho, pudemos observar, por meio de um levantamento de obras lidas por alunos do Ensino Fundamental, que, entre essas, $A$ ilha perdida, de Maria José Dupré, era considerada como atraente, já $A$ casa da madrinha, de Lygia Bojunga Nunes, de difícil leitura. A partir deste diagnóstico, objetiva-se neste texto, por meio do suporte teórico da estética da recepção, apresentar uma possibilidade de leitura dessas obras, na qual se considera o papel do narrador e sua interferência no papel do leitor implícito. Pretende-se também compreender o que torna atraente a obra de Dupré para os jovens e o que os leva a classificar, como difícil, a de Bojunga.

Considera-se, neste artigo, a literatura como sendo condicionada, tanto em seu caráter artístico, quanto em sua historicidade, pela relação dialógica entre obra e leitor. Para Jauss (1994, p.23), o leitor tem um "papel genuíno, imprescindível tanto para o conhecimento estético quanto para o histórico", visto que é para ele que a obra é direcionada. Essa relação decorre da presença de vazios no texto que, ao solicitarem do leitor um preenchimento, indicam os locais de sua entrada no universo ficcional (ISER, 1999, p. 107). Assim, um texto possui uma estrutura de apelo que invoca a participação de um indivíduo na feitura e acabamento: é seu leitor implícito. A comunicação ocorre quando esse leitor, na busca do sentido, resgata a coerência do texto interrompida pelos vazios. Para tanto, ele se utiliza de sua produtividade e, justamente por isso, obtém prazer na leitura.

De acordo com Regina Zilberman (1984, p.132), a fantasia é o setor privilegiado pela vivência do livro infantil e juvenil. De um lado, porque aciona o imaginário do leitor e, de outro, porque é o cenário em que o herói resolve seus dilemas pessoais ou sociais. Consequentemente, não é a saída que coloca o herói perante o mundo, mas a sua volta. Sendo assim, buscaremos observar qual é o estatuto que as personagens das duas obras adquirem no retorno do espaço da aventura.

\section{PERDIDOS NA ILHA}

A ilha perdida trata das peripécias vividas pelos irmãos Henrique e Eduardo, que saem escondidos da fazenda dos padrinhos, margeada pelo rio Paraíba, para se aventurar em uma ilha situada no centro desse rio. O chamado da aventura acontece por meio da sedução, pois os protagonistas sentem-se atraídos por aquele misterioso espaço proibido pelos adultos. Na ânsia de atingirem-no, encontram, por acaso, uma canoa velha, a qual os conduz ao lugar desejado. Esse espaço apresenta-se como desconhecido e de difícil acesso, pois constituído por matas fechadas e labirínticas. Nele, os protagonistas passam fome, sentem medo e correm risco de vida. O mais novo, Henrique, é detido por um ermitão, Simão, morador da ilha há muitos anos. Feito prisioneiro, o jovem adentra o centro da ilha, enquanto seu irmão permanece em suas margens. Henrique, uma vez 
liberto, reúne-se ao irmão e ambos retornam ao espaço domiciliar da fazenda, no qual são bem acolhidos.

Na narrativa, a intenção pedagógica transforma a aventura em pretexto para a transmissão de normas. Assim, seus heróis, no retorno da aventura, não obtêm um poder ou saber capaz de propiciar a conscientização e o reconhecimento. Como o ingresso na aventura é proveniente de uma transgressão à ordem, o espaço que a representa se transforma em lição aos desobedientes. Desse modo, a experiência propiciada pela aventura leva os protagonistas à aceitação das regras referentes à obediência, com consequente reclusão no âmbito familiar. Acompanhando a trajetória das personagens, os alunos reconhecem seu pequeno mundo somente quando elas regressam ao lar. Dessa forma, fecha-se o circuito doméstico e, dentro dele, está aprisionado o leitor implícito, cercado pela proteção dos adultos, levado a prestigiar a sua circunstância e a aceitar os papéis de dominadores exercidos por eles.

Em A ilha perdida, a aventura é marcada, também, por antíteses. Após o retorno dos heróis, o padrinho decide levá-los, bem como seus primos mais jovens, a uma expedição na ilha. Em todas as referências a esse passeio não há menção ao sol, antes a chuvas e tempestades, as quais obrigam os protagonistas a acatar a decisão do padrinho de retornarem para a fazenda. Esse regresso é marcado pela frustração, pois eles não conseguem encontrar o solitário Simão e, assim, provar a veracidade de seus relatos. Desse modo, o espaço externo, da aventura, representante da liberdade, apresenta somente frio, escuridão e desconforto. Somente o lar, espaço interno, atendendo ao modelo familista, é representante da luz e do conforto proporcionado pela família.

A exploração dos espaços conota os anseios das décadas de 1940 e 1950. O cenário primitivo, embora eldorado de riquezas, está superado, representa apenas um local abandonado, repleto de perigos e mistérios favoráveis à ação. Dupré, ao utilizar lugares exóticos e primitivos para compor a narrativa, segue a tendência apresentada pela Coleção Terramarear. Ela explora dos quadrinhos e das narrativas de aventura a sensação de produzir no leitor sonhos, estímulos e ideais, como a liberdade, a natureza e a força, mas todos com caráter escapista, por consequência, não emancipatório.

Dupré se utiliza do mundo natural em sua narrativa como locus e pretexto para o rito de "conformação". Embora a obra seja atraente por expressar os desejos do jovem leitor que, assim como as personagens, entediado com a clausura doméstica, anseia ingressar em uma aventura por lugares desconhecidos; por possuir intenção pedagógica, ridiculariza esses anseios, apresentando-os como infantis e infundados. Há, então, na obra, devido ao caráter utilitário, desvalorização da emoção, por isso praticamente inexistem conflitos entre as personagens. Os poucos existentes são fornecidos pelo espaço da aventura ou por pessoas que o representam.

O modelo familista também determina o comportamento das personagens. As jovens se conduzem como adultos em miniatura, compromissadas com a família, amadas por todos que a compõem, representam o mito do "jovem feliz". As adultas são modelos de conduta e moralidade, fornecem conselhos aos jovens e, por projeção neles, ao leitor empírico. Atuam como suporte para o pedagogismo da autora. Atendendo ao modelo de literatura trivial, as personagens adultas masculinas ingressam na aventura, pois são determinadas e 
competentes; as femininas permanecem em casa preocupadas e inconsoláveis, pois são frágeis. Elas representam mulheres pacientes e amorosas, todavia, por serem carentes de atenção, servem de justificativa para o bom caráter das personagens masculinas.

Devido ao perfil moralizante da narrativa, os animais se dividem em "bons" e "maus". Os primeiros são companheiros determinados e inseparáveis, obedecem aos seus donos, fornecem-lhes coragem e respeitam-nos; os últimos, desobedientes. Contudo, os animais exemplares são frágeis e precisam de cuidados constantes, servindo de motivo para justificar as "boas" ações dos humanos para com eles. Pela personificação dos sentimentos e comportamentos desses animais, eles conotam os jovens heróis que necessitam de amparo dos "mais velhos".

A obra, atrelada à "modernidade" da época em que foi escrita, explora a produção em série, por meio do aproveitamento dos mesmos personagens constantes em outras narrativas de Dupré. A sua temática filia-se à ideologia do período, representada pelo teor educativo e moralizante. Esse teor aparece nas caracterizações morais das personagens, tornando-as artificiais. Entretanto, é válido destacar que não são as qualidades morais que prejudicam a narrativa, mas a superficialidade e a falsidade do contexto em que as personagens estão inseridas, pois seus discursos e atitudes não convencem, comprometendo a verossimilhança. Há outros elementos que contribuem para esse comprometimento, como a localização da residência dos padrinhos: ora descrita como situada na fazenda ora em Taubaté, e o discurso paradoxal de Simão. A princípio, essa personagem atua como um "conselheiro", incentivando Henrique a proteger os animais indefesos. Em seguida, afirma que, se os homens anseiam medir "forças" com os animais, eles devem procurar, na África e na Índia, pelos desafiadores. Essa concepção revela uma idealização de um determinado tipo elitista de caça e tolerância com essa prática.

Pode-se observar, pela análise da narrativa, que a literatura não é concebida como agente formador, mas como manifestação retórica capaz de doutrinar o leitor. Desse modo, a obra expressa o que a camada dominante entende como literatura infantil e juvenil: uma propaganda de seu estilo de vida. Da leitura global, o leitor implícito pode concluir e, por projeção nele, o aluno leitor, que deve: respeitar os animais e os "inferiores", ser feliz e grato aos familiares e a Deus, apreciar a natureza e prezar o amor da família. A obra revela, então, em seu discurso uma poética preocupada com a transmissão de certezas, de alinhamentos rígidos do mundo. As mensagens apresentadas ordenam ao leitor implícito e, por projeção nele, ao empírico, como deve proceder. Esse autoritarismo no discurso revela que a autora concebe o seu leitor como inferiorizado, diante de um emissor adulto detentor de "verdades".

Na narrativa, a fantasia aparece de forma escapista, como sucedâneo do sonho, alienante. Ao término da aventura, os adultos não acreditam na veracidade dos relatos dos jovens protagonistas, pensam que eles deliraram ou imaginaram. A manifestação dessa desconfiança, associada à falta de provas no retorno da ilha, faz com que esses jovens se conformem com as suspeitas. Assim, a fantasia não ilumina a realidade, não emancipa o seu leitor, pois interessa à autora menos a estética do que a inculcação de moralidades compatíveis com o grupo a que ela pertence. 
A obra copia processos da cultura de massa, porque correspondem ao padrão de qualidade a ser atingido. Ela expressa a perda da conotação do espaço primitivo como local de trabalho, por isso a estada das personagens em uma ilha deserta é provisória, pois ela não possui apelos para retê-las. Esse cenário representa um Brasil arcaico que desaparece por força das mudanças históricas e deseja tornar-se urbano e progressista. Justifica-se, então, que as personagens residam no espaço urbano e dirijam-se ao primitivo sempre a passeio ou nas férias, sem comprometer o período de aula na escola. Somente residem no espaço rural, na fazenda, as jovens personagens Quico e Oscar, e seus pais, os padrinhos. Entretanto, esse espaço não é isolado, situa-se nas proximidades de uma cidade: Taubaté.

Enquanto estão no espaço urbano, os heróis idealizam o natural, buscam-no pela possibilidade de liberdade e de aventura que representa. Ao sobreviverem a essas aventuras, eles retornam ao espaço de onde partiram, com a certeza de que se aventurar foi um erro. Logo, os adultos têm razão em proibi-los de visitar o espaço primitivo. As conclusões a que chegam os protagonistas atuam também como suporte para o pedagogismo da autora, pois os seus sofrimentos servem de "lição" exemplar e aviso a quem pretende ausentar-se do espaço domiciliar: o leitor implícito. Desse modo, a autora utiliza-se, para transmitir suas "mensagens", de dois elos visíveis que o leitor empírico encontra com o texto: a personagem e o leitor implícito.

O espaço da aventura conota, também, a oposição entre organização civilizada e primitiva, pois, embora se valorize a natureza como necessária à subsistência e à exploração, o local que a contém aparece como superado. Por isso, a permanência das personagens na ilha representa um perigo latente: o de romperem com as coordenadas do "sistema social" da classe dominante. Dentro desse sistema, o local ideal para elas é o do lar, onde são protegidas e amadas. Ao final da leitura, as próprias personagens percebem e, por projeção nelas, também o leitor empírico, que a excursão aventuresca foi em vão. Mesmo o desejo manifesto por Henrique de um dia voltar sozinho à ilha para não afugentar a personagem Simão, só poderá ser concretizado quando ele for adulto. Como não há provas de que Simão exista, esse desejo é infundado.

A obra elabora um modelo de vida familiar característico de boa parte da narrativa infantil e juvenil de 1940 e 1950, pois privilegia o valor da existência doméstica, encerrando nela as jovens personagens porque se trata de seu mundo verdadeiro. Desse modo, transparece a euforia com a vida administrada pela família que lega a seus rebentos os principais padrões da sociedade. Os espaços, por sua vez, confirmam esse modelo.

A narrativa aparece marcada pela intenção básica do narrador tradicional de contar uma história interessante sobre uma aventura no interior de uma ilha misteriosa. Esse tema faz parte da linha heroico-aventuresca que, no transcorrer dos tempos, tem encontrado a mais alta ressonância entre leitores diversos. Contudo, o narrador apresenta um discurso judicativo, que interpreta e decodifica, por meio de juízos e digressões, as emoções e os sentimentos dos heróis. Assim, seu discurso estrangula a autonomia das personagens em expressar seus próprios questionamentos e, por consequência, a liberdade do leitor implícito em interpretá-los. 
O discurso do narrador, estruturado como um comentário didático autorizado da ação, orienta-se para esse leitor com a intenção de agir sobre ele. Afirma-se, então, a sua função ideológica: levar o jovem leitor à aceitação dos valores impostos pelos adultos. O monopólio do narrador resulta em autoridade soberba, sendo impossível aos heróis contestarem o privilégio de seu comentário ideológico. Como se trata de um narrador que defende a ideologia dos adultos, ele os conota e, na opressão às jovens personagens e ao leitor implícito, mimetiza-os. O leitor implícito, assim como o empírico que nele se projeta, vê-se, mesmo no universo ficcional, na fantasia, preso às normas adultocêntricas.

A soberania do narrador sobre o leitor implícito avulta quando se exclui a decodificação do destinatário. Ao leitor é fornecido um mundo pronto, previamente interpretado e facilmente consumível. Com isso, impõe-se um processo de percepção textual no qual o recebedor é colocado perante um produto acabado que, se é opressivo no âmbito ideológico, é digerível sob o aspecto estético. Desse modo, caminham juntas na obra: facilidade de leitura e transmissão de valores repressivos. É válido destacar que o prazer manifesto pelos alunos, na leitura, advém, justamente, dessa facilidade. Como se pode observar, o discurso do narrador, por atender a um projeto estético pedagógico condutor de ideologias, não propicia uma comunicação interativa com o leitor.

A ilha perdida, por apresentar contenção comunicativa, assegura o mesmo que os produtos da literatura trivial: a sedução do consumo fácil. Sua narrativa é construída para favorecer ao entretenimento e incutir as ideologias dos adultos. Justifica-se, então, a ausência de novidade formal e o questionamento existencial; a mesmice nas ações das personagens no espaço da aventura; a apresentação linear do tempo na diegese; e o final "fechado". A opção de Dupré por esse "fechamento", que elucida o destino definitivo das personagens, tem por objetivo produzir no leitor atordoado com o caos social à sua volta a sensação de "consolo". Pela leitura, ele se depara com uma narrativa organizada que lhe transmite a impressão de que domina a sequência de eventos, podendo inclusive antevê-los.

\section{NA CASA DA MADRINHA}

A obra A Casa da Madrinha, publicada no ano de 1978, narra as aventuras e desventuras de Alexandre, morador de uma das favelas do Rio, que vende amendoim e sorvete nas praias da sua cidade. Um dia, ele resolve procurar a "casa da madrinha", em que todas as suas carências seriam resolvidas.

Durante sua viagem, encontra-se com um pavão, o qual se torna seu companheiro e ajudante nos shows que Alexandre improvisa para ganhar alguns trocados e poder sobreviver. Nas suas andanças, acaba chegando a uma cidade pequena do interior. Lá, conhece Vera com quem trava uma grande amizade. Nesse espaço, ambos vivem aventuras que misturam o plano da realidade ao da fantasia.

Segundo Nelly Novaes Coelho, Bojunga enfoca, nesse livro, os duros problemas de sobrevivência na cidade grande ou no meio rural, e transmite a ideia de que o sonho e a esperança devem acompanhar o ser humano para que a jornada se torne mais fácil. Analisando a proposta ideológica da obra de Bojunga, a estudiosa entende que a "casa da madrinha" revela-se como "[...] uma bela 
metáfora do grande Ideal que todo homem deve perseguir em sua luta pela vida" (1984, p. 566).

Para tratar desse tema, o modo como Bojunga narra seu texto diferencia-o de outros considerados utilitários. Na narrativa da escritora, há um trabalho literário, artístico, com as palavras. 0 texto possibilita ao leitor vivenciar novas experiências, ao socializar com as personagens, por meio de um discurso inovador, ele se depara com o drama íntimo de Alexandre, Augusto e Vera. Por identificação, ele se projeta nesses protagonistas e reflete sobre suas ações. A narrativa solicita, assim, um leitor ativo, criativo e com empatia pela dor do outro.

A trama da história inicia com Alexandre chamando o pessoal da cidade para a apresentação de um show com o pavão. Após o show, ele se depara com Vera e inicia um diálogo, no qual se descortina, gradativamente, fornecendo informações sobre onde morava, o que fazia e como vivia. Da mesma forma, Vera conta sobre sua família, seus pais, o que fazem, como é sua vida. Alexandre relata as dificuldades que a família viveu e a necessidade dele em ajudar no sustento familiar vendendo biscoito, amendoim, sorvete na praia. Conta como foi sua viagem e de que modo conhecera o pavão.

De um ponto de vista histórico, ao narrar o encontro de Alexandre com o pavão, a obra denuncia o contexto da ditadura, visto que ele passa por três cursos - "Curso Papo", "Curso Linha" e "Curso Filtro" -, com o intuito de ser doutrinado. Esse episódio, além de revelar as transformações ocorridas no ensino após o golpe de 1964, contrapondo dois tipos de ensino - um com visão negativa e outro com visão positiva -, mostra a atitude autoritária e repressora desse período.

A escola, onde o pavão fora obrigado a estudar, chamava-se OSARTA. Curiosamente, essa palavra, ao contrário, forma outra: ATRASO. Percebe-se a crítica da autora em relação ao ensino autoritário que tolhe a criatividade do aluno. Os três cursos têm esse intuito. No "Curso Papo", embora tenha esse nome, o aluno não podia falar, apenas ouvir o que diziam. Era uma espécie de aula com lavagem cerebral:

[...] ele [o pavão] não podia achar nada; tinha que ficar quieto escutando o pessoal falar. Se abria o bico ia de castigo; se pedia pra ir lá fora ia de castigo; se cochilava (o pessoal falava tanto que dava sono), acordava ele correndo pra ele ir de castigo (BOJUNGA, 2002, p. 24).

Além disso, tinha o objetivo desse curso era o de aterrorizar o aluno e fazer com que ficasse com o pensamento atrasado, não pensasse, não refletisse e nem questionasse sobre qualquer coisa: 
martelavam o dia inteiro no ouvido do Pavão (BOJUNGA, 2002, p.24).

No "Curso Linha", costuraram o pensamento do pavão. No entanto, a linha não era de qualidade, dessa forma, o pavão, ao perceber isto, treina até conseguir dar um puxão no pensamento e, assim, arrebentar a linha. De tanto arrebentá-la, os donos do pavão desistiram desse método e colocaram-no no "Curso Filtro".

A intenção desse curso reside em seu próprio nome: filtrar o pensamento. Puseram o tal filtro na cabeça do pavão e deixaram a "torneira de seus pensamentos", apenas, um pouco aberta. Entretanto, o filtro veio com defeito de fábrica e não ficava regulado no mesmo lugar. Assim, às vezes, a torneira abria por inteiro e o pensamento do pavão se normalizava. Embora, a maior parte, ficasse na posição como deveria ficar, só um pouco aberta, para o "[...] pensamento do Pavão pingar bem devagar e ir ficando cada vez mais atrasado" (BOJUNGA, 2002, p. 29).

Em contrapartida, há a escola de Alexandre. Neste espaço, a autora nos apresenta uma professora diferente, conhecida como sendo a da maleta. Ela representa a profissional ideal, criativa, inovadora, compromissada com a educação e o aprendizado dos alunos. Ela consegue cativá-los com várias atividades diferentes, pois possui propostas inovadoras de ensino. Em suas aulas, as crianças aprendem de forma prazerosa e lúdica, fugindo totalmente do ensino tradicional. A Matemática é ensinada, por meio da receita de bolinho de trigo; o Português, por viagens pelas histórias ficcionais; a Ciência, pelo dia da higiene corporal; a Geografia e a História, por meio das brincadeiras do "dia de viajar".

$\mathrm{Na}$ sua maleta, a professora tinha vários pacotes que continham os conteúdos a serem ministrados, a cada aula havia uma surpresa. O pacote "corde-burro-quando-foge" era posto pela professora em cima da mesa, mas ela nunca o abria. Pode-se inferir que esse pacote representa a aula tradicional, aborrecida, pois desvinculada dos interesses dos alunos. Ela ensinava os conteúdos de forma inovadora, lúdica, explorando o psicológico e o contexto do aluno, fugindo totalmente do ensino tradicional. No entanto, seu método não era aceito pela direção, nem pelos pais, por isso a professora foi demitida. Esse dado demonstra a percepção da autora de que as expectativas sociais, ainda, se direcionam para o ensino tradicionalista.

A narrativa sobre a história do pavão é feita pelo recurso da analepse, momento em que a história volta ao passado e Alexandre relata a Vera toda sua vida. O garoto conta das dificuldades da família, da necessidade de ajudar no sustento familiar e de ter que abandonar os estudos. Em meio a essa situação difícil e com dificuldades para dormir, Alexandre descobre, pelo relato de seu irmão Augusto, a história da casa da madrinha. Essa narração da casa da madrinha é feita de forma edênica, paradisíaca, pois a apresenta como um lugar em que todos os desejos são realizados. Verifica-se durante a narração que a "casa da madrinha" é carregada de simbologia. Ela representa a utopia que todos nós devemos ter, para conseguirmos superar os obstáculos com os quais nos deparamos na vida. Desde a primeira vez em que essa casa é mencionada por Augusto, ela assume essa conotação. Quando Augusto fala de sua madrinha, Alexandre logo pensa em sua madrinha real, dona Zefa, que considera chata. No 
entanto, Augusto vai falando dessa outra madrinha que mora no interior, em uma casa branca, pequena, de quatro janelas, que fica no alto de um morro rodeado de flores. Neste espaço, pode-se ver de um lado o mar e de outro, o mato. O local é idílico, bucólico, fazendo lembrar a música "Casa no campo", de Zé Rodrix e Tavito ${ }^{2}$ (Luís Otávio de Melo Carvalho).

Nessa descrição, há, ainda, a mistura de sonho e realidade, pois prevalece nos elementos que compõem a casa a personificação e a sinestesia. Assim, sua porta é azul, cor que ela mesma escolheu, e possui uma flor amarela bem no peito, para se enfeitar. Percebe-se o animismo na constituição dessa porta, já que possui o poder de escolher, tem peito e se enfeita. Vale destacar que as cores azul e amarela são predominantes nas narrativas de Lygia Bojunga Nunes, assumindo efeitos de sentido. $\mathrm{O}$ azul, segundo Chevalier e Gheerbrant:

É a mais profunda das cores: nele, o olhar mergulha sem encontrar qualquer obstáculo, perdendo-se até o infinito, como diante de uma perpétua fuga da cor. O azul é a mais imaterial das cores: a natureza o apresenta geralmente feito apenas de transparência. ... Aplicada a um objeto, a cor azul suaviza as formas, abrindo-as e desfazendo-as. ... Imaterial em si mesmo, o azul desmaterializa tudo aquilo que dele se impregna. É o caminho do infinito, onde o real se transforma em imaginário. ... O azul é o caminho da divagação, e quando ele se escurece, de acordo com sua tendência natural, torna-se o caminho do sonho. O pensamento consciente, nesse momento, vai pouco a pouco cedendo lugar ao inconsciente, do mesmo modo que a luz do dia vai-se tornando insensivelmente a luz da noite, o azul da noite (1988, p. 107).

Enquanto o amarelo, para os dois estudiosos representa algo:

Intenso, violento, agudo até a estridência, ou amplo e cegante como um fluxo de metal em fusão, o amarelo é a mais quente, a mais expansiva, a mais ardente das cores, difícil de atenuar e que extravasa sempre dos limites em que o artista desejou encerá-la. Os raios do Sol, atravessando o azul celeste, manifestam o poder das divindades do Além. ... No par Amarelo-Azul, o amarelo, cor masculina, de luz e de vida, não pode tender para o esmaecimento (1988, p.107).

No romance, percebe-se bem a presença dessas simbologias das cores, visto que o azul da porta é bem forte, através do qual o olhar ultrapassa qualquer obstáculo. Além disso, a porta é fácil de abrir e possui duas chaves: uma que a abre por dentro e outra, por fora. Entretanto, a chave está dentro da flor amarela e é preciso que Alexandre consiga pegá-la. Para isso, ele precisa dominar o medo. Justifica-se, então, a cor dessa flor, capaz de facultar, pela sua vibração intensa, 
coragem para o protagonista não desistir de seu intento. Dominar o medo, assim como ter a chave, significa amadurecer, superar os obstáculos, ser perseverante nos seus sonhos, conseguir abrir a porta de seus desejos. E a casa da madrinha possui a realização de todos os desejos: cadeira que estica, conforme o pedido; armário, com roupas as quais se deseja; prateleira, com sapatos de que se gosta; armário, com comidas à escolha. Além disso, possui mar com água morna e quintal com árvores, cascatas, rios, gruta, caverna, enfim, mistérios para desvendar. A casa representa, então, o espaço ideal, já a cidade, o espaço da civilização que corrompe o homem.

Alexandre parte com o objetivo de encontrar a "casa da madrinha", pois sua família está passando por dificuldades. Ele mora na favela em Copacabana com sua mãe, dois irmãos e duas irmãs. Sua mãe lava e passa para fora, as irmãs são empregadas domésticas, o irmão mais velho e Augusto vendem sorvetes na praia, o pai é alcoólatra e não trabalha, vive caído pelo chão. Com o tempo, as dificuldades vão aumentando: uma das irmãs, que ajudava nas despesas, casa-se, e o irmão mais velho é internado no hospital por causa de uma doença séria que contraiu. Assim, Alexandre começa a ajudar, vendendo amendoim aos domingos e depois, aos sábados. Nas férias, ele trabalha todos os dias, a não ser quando chove.

As aulas recomeçam, mas Alexandre não volta à escola, pois Augusto resolve se casar e deixa de ajudar nas despesas da casa. Alexandre, então, começa a vender sorvete, mais rendoso, embora mais pesado de carregar. Até que, certo dia, Augusto vai trabalhar em uma fábrica em São Paulo, deixando Alexandre desconsolado. Para piorar a situação, começa o inverno no Rio e não há como vender sorvete na praia. Resolve, então, ir ao centro pegar táxi para freguês. No entanto, já havia crianças que faziam esse tipo de "trabalho", o que exclui a iniciativa de Alexandre. Essa situação é o reflexo dessa sociedade capitalista em que o dinheiro passa a ter papel preponderante, gerando diferenças sociais e miséria. Com a situação cada vez mais difícil e pelo fato de Augusto não retornar mais para casa, Alexandre resolve ir à procura da "casa da madrinha", no interior. Desanimado com a situação, sai em busca de seu ideal. Explorando seu talento individual, supera gradativamente obstáculos para poder sobreviver, durante a longa viagem.

Por meio do relato de Alexandre, Vera fica sabendo o porquê deste menino da cidade grande ter vindo para uma cidade do interior. Nota-se que, enquanto Alexandre representa o menino da classe social pobre, Vera representa a classe social melhor estruturada, oposta a de Alexandre. A menina mora com sua família - mãe e pai -, que possui um sítio com plantação de flores, de onde tira o sustento. Ela estuda, tem deveres e horários a cumprir, mas não passa por necessidades como Alexandre. Além disso, ela tem uma visão mais realista da vida, enquanto Alexandre é sonhador. Parece que, como forma de enfrentar a triste realidade, ele precisa viver em uma dimensão onírica. Esse fato pode ser exemplificado com a dúvida de Vera, se, realmente, Alexandre possuía uma madrinha ou não.

Os pais de Vera não aceitam a amizade entre eles, pois têm preconceito contra o menino - pobre, sem família, "[...] garoto que vive à toa na estrada" (NUNES, 2002, p.73). Assim, pedem para Vera dizer a Alexandre que vá embora do sítio, pois "[...] já tinham dado comida pra eles, já tinham deixado eles ficarem um dia e uma noite no sítio" (NUNES, 2002, p.71), além de dinheiro para comida 
de uns três dias. Isso deixa Alexandre muito zangado, pois não concorda com a visão dos pais de Vera:

- Como é que eu tô à toa na estrada se eu tô indo pra casa da minha madrinha?!

Vera não gostava quando gritavam com ela; zangou também:

- Mas tá na cara que você não tem madrinha nenhuma! Aquilo tudo foi história que o Augusto inventou pra você dormir! (NUNES, 2002, p. 74).

Entretanto, quando Vera argumenta que era a opinião de seus pais, Alexandre compreende, pois, para ele, os adultos não possuem sensibilidade. Segundo Alexandre, os adultos sentem inveja das madrinhas das crianças. Assim, Alexandre, em vez de se despedir e enfrentar a dura realidade, resolve inventar um cavalo, mergulhando novamente no mundo onírico. Ele se chama Ah, é amarelo, de rabo cor de laranja, arrastando no chão. Pela cor, ele se configura como um símbolo de renovação e, pela significação da interjeição que compõe o seu nome, como uma descoberta. Alexandre e Vera pulam com ele a cerca que limita o sítio, representação da fronteira da liberdade. Ao ultrapassarem o proibido, só encontram a escuridão, o medo, o castigo pela desobediência. Assim, para superarem o medo, desenham no escuro, "desconstruindo" este sentimento negativo e construindo outro positivo: a esperança. Com esse ato, Alexandre e Vera ultrapassam fronteiras geográficas e psíquicas, levando-os à realização do sonho. Alexandre, ao desenhar uma porta com maçaneta, fechadura, chave e tudo, faz com que a porta se abra, ao girar a chave. Assim, ele e Vera encontram a casa da madrinha, onde todos os sonhos são realizados.

Verifica-se que, no texto de Lygia Bojunga, não é por meio da voz do adulto que a sanção é imposta à criança, pelo contrário, a própria criança percebe que cometeu uma transgressão e se sente amedrontada. Contudo, como é competente, encontra meios de superar suas angústias. A desobediência é tratada de maneira que leve a criança a refletir sobre o seu ato e não, simplesmente, sentir-se culpada e ser castigada pelos adultos ou pelos elementos presentes no espaço da aventura. Desse modo, o enredo eleva a autoestima da criança, pois a representa como capaz de encontrar meios para superar situações de conflito.

O pavão, símbolo do período de repressão, cura-se das torturas sofridas. A Gata, namorada do pavão, aparece também na casa da madrinha. Ela tinha desaparecido, pois não conseguira escapar da própria casa, quando a demoliram para construir um edifício. A maleta da professora de Alexandre, que havia sumido, reaparece também. Augusto retorna, enfim, cumprindo a promessa feita ao irmão e surpreendendo a todos na casa da madrinha. Ele representa o grande contador de histórias, que faz com que Alexandre viaje no mundo da imaginação. Dessa forma, além desses desejos mais íntimos, os vitais, como habitação, alimentação e vestimenta, também, são atendidos.

Vera, entretanto, desperta do mundo da fantasia e lembra-se das horas. Essa garota, por ter sido, pelos pais, sempre cobrada para cumprir seus deveres e 
nunca se esquecer das suas obrigações, não consegue se desligar totalmente do mundo real. Assim, ela resolve ir embora sozinha, pois Alexandre ficaria muito bem na casa da madrinha com seu irmão Augusto e todos os desejos realizados. Não precisaria mais sentir "[...] um buraco danado na barriga" (NUNES, 2002, p. 46). Contudo, quando estava partindo, a janela que vivia empenada resolve abrir só por desaforo, acordando todo mundo. Todos resolvem voltar com Vera, mas, ao chegarem do outro lado, percebem que o Augusto e a Gata não tinham vindo, embora também tivessem montado no cavalo. O Pavão também voltou a pensar pingado como antes. O cavalo Ah foi desaparecendo, precisando ser inventado novamente. Tudo retorna de acordo com a realidade. Portanto, era preciso sair novamente à busca do mundo onírico, da "casa da madrinha".

Percebe-se que Lygia Bojunga constrói sua narrativa, pelo viés literário, misturando, para tanto, sonho e realidade, rompendo e fundindo os limites de um e de outro. A imaginação no seu construto transcende e passa a ser parte integrante da realidade. Não se sabe ao certo se a história narrada por Augusto sobre a madrinha de Alexandre é verdadeira ou apenas uma história inventada para ele dormir e enganar a fome. Isso é, inclusive, questionado por Vera e por seus pais. Apesar de Vera ter a experiência utópica de conhecer a "casa da madrinha" com Alexandre, ela não consegue se envolver totalmente nessa utopia. No momento em que Alexandre vai se despedir dela, ele vê a flor amarela em sua caixa e diz:

- Olha a flor amarela que enfeitava o peito da porta azul. Como é que ela veio parar na minha mala? Foi você que botou ela aqui?

Vera olhou a flor; olhou Alexandre; "por que será que ele tá achando que a flor que eu botei na mala é a flor que enfeitava a porta azul? Essa alamanda é muito menor..."

Alexandre enfiou a mão na flor pra pegar a chave da casa.

Vera pensou: pronto, agora ele vai ver que é uma outra flor.

Alexandre pegou a chave e guardou no bolso.

- Que legal! Agora vou viajar com a chave da casa no bolso; não vou ter mais problema nenhum. Lembra o que o Augusto falou?

Vera ficou olhando pra flor sem entender (NUNES, 2002, p. 93-94).

Assim, percebe-se que, em Alexandre, a inquietação, o estado de devir é perpétuo, bem como a interrogação, a procura e a luta sempre o acompanham, pois ele necessita disso para poder viver devido às suas carências. A incompletude está presente nele, justamente por isso, ele se configura como mais humano e atraente para o leitor. Este protagonista é um ser que está sempre em transformação, metamorfoseando, alçando voos, saindo de seu mundo interior para o exterior, interagindo, socializando com outros para crescer. Logo, tanto Alexandre, como Augusto falam que precisam seguir a vida 
toda até encontrar a "casa da madrinha", é a busca utópica sem fim que os define.

Para Vera, "[...] toda a vida é tão comprido" (NUNES, 2002, p.93). Assim, pelo fato de não sentir essas carências, ela não se entrega totalmente à fantasia. Essa personagem representa o ser preso ainda às convenções, às normas, às obrigações, ao relógio, às horas.

\section{ALGUMAS CONSIDERAÇÕES}

Pode-se concluir que o consumo da obra $A$ ilha perdida está assegurado, mesmo no século XXI, por diversos fatores. Pelo seu caráter ideológico, ela agrada aos adultos que a disponibilizam para leitura. Por apresentar processos formais próprios da cultura de massa, atende aos jovens com pouco contato com textos diversos e excessiva exposição a produtos da literatura trivial. A obra conforta o jovem leitor, porque atende ao seu horizonte de expectativa. De acordo com Jauss, obras como $A$ ilha perdida, atendem o horizonte de expectativa,

pelo fato de não exigir nenhuma mudança de horizonte, mas sim de simplesmente atender as expectativas que delineiam uma tendência dominante do gosto, na medida em que satisfaz a demanda pela reprodução do belo usual, confirma sentimentos familiares, sanciona as fantasias do desejo, torna palatáveis [...] (1994, p.32).

Elegendo-a para leitura, ele evita realizar um complexo exercício de raciocínio e interpretação, geralmente, exigido por obras críticas e provocadoras. A editora, por sua vez, ciente de que a obra possui demanda, mantém-na em circulação.

A ilha perdida aproxima-se dos textos da chamada literatura de tese, nos quais um discurso domina univocamente, pois produzido por um emissor que conhece e prevê com bastante exatidão a enciclopédia e volitivas do leitor ideal (SILVA, 1993, p. 328). Esse leitor, projetado por Dupré, habituado ao mínimo esforço, busca na leitura entretenimento e consumo fácil. Ao atender a seus anseios, a autora limita o número de vazios em sua obra, impedindo que a produtividade do leitor implícito entre em jogo na leitura. Por consequência, há um estreitamento da atividade imaginativa do leitor que, ao receber a obra de tal forma estruturada e fechada à sua interpretação, não tem condições de projetar uma nova realidade àquela apresentada. Então, guiado pela ótica do narrador, só pode manifestar atitudes de aceitação ou rejeição acerca das normas e valores expressos na narrativa.

O texto de Bojunga, ao contrário, solicita a produtividade do leitor que, na ânsia de compreender seus símbolos e sua linguagem metafórica, realiza a projeção imagética e, por consequência, projeta-se nas personagens, identificando-se com seus dilemas e medos. As jovens personagens, por sua vez, são falhas, equivocam-se, por isso são atraentes para o leitor, permitindo-lhe 
identificação e projeção. Como nem todas conseguem, graças à vivência, mergulhar sem reservas no universo onírico, elas, também, representam as limitações de sujeitos presos ao pragmatismo e, por isso, incapazes de ampliar seu imaginário.

Dupré, ao subordinar seu texto ao horizonte de expectativa de seus leitores, que esperam ser guiados sem esforço por um narrador, mesmo precisando suportar seus julgamentos e comentários didáticos, objetiva que eles, também, se subordinem ao ponto de vista da obra. A escritora, ao eleger esse narrador controlador, opta pela perda da qualidade da narrativa em favor da pedagogia. Desse modo, resulta em sua obra uma assimetria que impossibilita amenizar o contraste entre o poder do narrador e a dominação do leitor implícito, condenando a obra, por não ter uma solução esteticamente convincente, a não atingir o estatuto estético.

Já a obra de Bojunga, por relativizar o papel do narrador e apresentar tanto os adultos, quanto os jovens como passíveis de erros, revela-se libertária, pois não idealiza um e outro, justificando a validade do discurso de ambos, sem sobrepô-los. Em A casa da madrinha, Bojunga atinge o estatuto estético, tanto pela exploração da linguagem, quanto pela abertura do desenlace da narrativa que obtém sua concretude na interpretação do leitor.

Pode-se notar, na comparação entre as obras, que Bojunga assume perspectiva bem diversa da de Dupré. Na obra de Nunes, o campo é local ideal para a realização dos sonhos e emancipação dos medos e a casa familiar não é idealizada. Já em Dupré, o campo é apenas espaço de lazer, indicado para curtos períodos de permanência, pois a cidade e a casa familiar são espaços ideais para a permanência dos jovens.

No que diz respeito à fantasia, a obra de Bojunga configura-se como simbólica e rica em imagens. Suas personagens, jovens ou animais possuem o mesmo estatuto, não se classificam nem como boas ou más, pois não prevalece o maniqueísmo. A obra de Dupré, por sua vez, prima pelo realismo, inclusive na identificação dos espaços. Além disso, sua abordagem é maniqueísta, por isso divide as personagens entre boas - obedientes e cordatas - e más desobedientes e rebeldes.

Pelo exposto, verifica-se que conhecer as obras eleitas como atraentes ou classificadas como difíceis pelos alunos, permite detectar os seus horizontes de expectativa. Justamente, esse tipo de diagnóstico faculta ao mediador propor outras leituras que, situadas no eixo da ruptura, facultam a esses alunos a ampliação de seus horizontes e de suas perspectivas estéticas. 


\title{
The narrative speech in The Lost Island, by Maria José Dupré, And The Godmother's House, by Lygia Bojunga
}

\begin{abstract}
This paper aims to examine the provisions of the narrator in two discursive books of two different authors: Maria José Dupré's The lost island and Lygia Bojunga Nunes' The godmother's house. To achieve this goal, we intend to observe why Dupré's book, which is marked by a monologic discourse and by the sovereignty of the narrator, is considered attractive by young people, and the work of Bojunga, characterized by a polyphonic discourse, is pointed out by young readers as a difficult reading. Through the theoretical support of reception aesthetics, we present a possibility of reading both books reflecting on the provisions of the narrator and his interference in the role of the implied reader. Furthermore, we intend to reflect on the horizon of expectation of young readers who approve Dupré and reject Bojunga.
\end{abstract}

KEYWORDS: Narrator. Reading. Reception aesthetics. Horizon of expectation. 


\section{REFERÊNCIAS}

CHEVALIER, Jean; GHEERBRANT, Alain. Dicionário de símbolos. São Paulo: José Olympio, 1988.

COELHO, Nelly Novaes. Dicionário crítico da literatura infantil/juvenil brasileira (1882/1982). São Paulo: Quíron, 1984.

COELHO NETO, José Teixeira. O que é utopia. São Paulo: Abril cultural Brasiliense, 1985. p. 7-9. (Coleção Primeiros Passos).

DUPRÉ, Maria José. A ilha perdida. Ilustr. Edmundo Rodrigues. 11. ed. São Paulo: Ática, 1978.

ISER, Wolfgang. $\mathbf{O}$ ato da leitura: uma teoria do efeito estético. Trad. Johannes Kretschmer. São Paulo: Ed. 34, 1999, vol.2.

JAUSS, Hans Robert. A história da Literatura como provocação à Teoria Literária. São Paulo: Ática, 1994.

NUNES, Lygia Bojunga. A casa da madrinha. Ilustr. Regina Yolanda. 18. ed. Rio de Janeiro: Agir, 2002.

PERROTTI, Edmir. O texto sedutor na literatura infantil. São Paulo: Ícone, 1986.

SILVA, Vitor Manuel de Aguiar. Teoria da literatura. 8. ed. Coimbra: Almedina, 1993, vol.1.

ZILBERMAN, Regina. A literatura infantil e o leitor. In: MAGALHÃES, Ligia Cadermatori. Literatura infantil: autoritarismo e emancipação. 2. ed. São Paulo: Ática, 1984, p. 61-134. 
Recebido: 17 abr. 2017

Aprovado: 19 jun. 2017

DOI: 10.3895/rl.v19n24.6029

Como citar: Matsuda, Alice Atsuko; FERREIRA, Eliane Aparecida Galvão Ribeiro. O discurso narrativo em Ilha Perdida, de Maria José Dupré e A casa da madrinha, de Lygia Bojunga. R. Letras, Curitiba, v. 19, n. 24 p. 115-131, mar. 2017. Disponível em: <https://periodicos.utfpr.edu.br/rl>. Acesso em: XXX.

Direito autoral: Este artigo está licenciado sob os termos da Licença Creative Commons-Atribuição 4.0 Internacional.

(c) (1) 